\title{
Alkylation of H-Phosphinate Esters under Basic Conditions
}

\author{
Isabelle Abrunhosa-Thomas, Claire E. Sellers, and Jean-Luc Montchamp* \\ Department of Chemistry, TCU Box 298860, Texas Christian University, Fort, Worth, Texas 76129
}

\begin{abstract}
An efficient and general procedure was developed for the direct alkylation of $\mathrm{H}$-phosphinate esters with LiHMDS at low temperature. The simplicity of the reaction allows the use of various $\mathrm{H}$ phosphinate esters and takes place with a wide range of electrophiles. The approach can be employed to access some GABA analogs or precursors to GABA analogs. The isolated yields are moderate to good. This is the first report of an alkylation with a secondary iodide, or a primary chloride.
\end{abstract}

\section{Keywords}

Alkylation; H-Phosphinate; Phosphinic Acid; Lithium; Hexamethyldisilazide

\section{Introduction}

Over the years, many examples of base-promoted H-phosphinate alkylation (eq 1) have been reported in the literature. ${ }^{1}$ However, there does not appear to be a standard set of conditions, and surprisingly, we have not found any general study of this reaction. Various bases (RONa, $\mathrm{NaH}, \mathrm{BuLi}, \mathrm{LDA}, \mathrm{KHMDS}$ ) and stoichiometries have been employed. ${ }^{1}$ A somewhat more widely employed approach (eq 2) consists of silylating H-phosphinic acids, followed by an Arbuzov-like reaction with alkyl halides. ${ }^{2}$ This method also has its limitations, and it often requires esterification of the dialkylphosphinic acid products when further manipulations are desired.

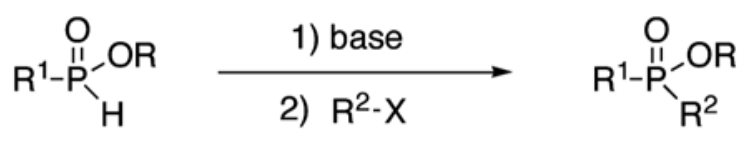

base $=\mathrm{Na}, \mathrm{NaH}, \mathrm{BuLi}, \mathrm{LDA}, \mathrm{KHMDS}$

(1).

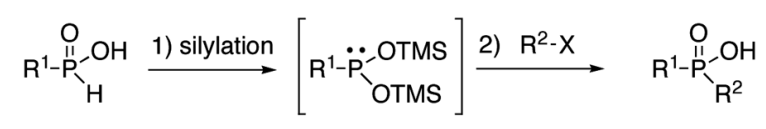

(2).

Functionalized, differentially-substituted phosphinate esters $R^{1} R^{2} P(O)(O R)$ are important organophosphorus intermediates, particularly in the synthesis of medicinally-relevant protease

j.montchamp@tcu.edu.

Alkylation of H-Phosphinate Esters

Fax: (+1) 817257 5851, Phone: (+1) 817257 6201, E-mail: j.montchamp@tcu

BRIEFS. The synthesis of differentially disubstituted phosphinic esters is conducted via alkylation of H-phosphinate esters under basic conditions. 
inhibitors and ATP-dependent ligases. ${ }^{3}$ Over the past few years, our laboratory has been developing various approaches to prepare $\mathrm{H}$-phosphinic acids and esters. ${ }^{4}$ With these compounds becoming more widely available, we are turning our focus to the functionalization of these intermediates with the formation of a second phosphorus-carbon bond. Our literature survey uncovered the lack of general conditions for the base-promoted alkylation of $\mathrm{H}$ phosphinates with alkyl halides. We therefore decided to investigate the scope and limitations of this transformation. Herein, we report a detailed investigation which led to a standardized set of conditions allowing the preparation of functionalized dialkylphosphinates.

\section{Results and Discussion}

Butyl octyl-H-phosphinate was selected as test substrate to determine the choice of base, with $n$-butyl iodide as the electrophile (Table 1). The phosphorus nucleophile, butyl iodide, and base were used in equimolar quantities, and the results studied by ${ }^{31} \mathrm{P}-\mathrm{NMR}$ of the crude reaction mixtures. Although alkylation takes place in all cases, significant differences are observed. Not surprisingly, nucleophilic bases, such as MeLi and BuLi (entries 3 and 4), give lower yields due to the competing direct substitution of the butyl ester to form a secondary phosphine oxide, whereas the strong non-nucleophilic bases (entries 5 and 6) give better results. After this initial screening, LiHMDS was selected to investigate the influence of the electrophile.

Table 2 summarizes the results obtained in the LiHMDS-mediated alkylation of $\mathrm{PhP}(\mathrm{O})(\mathrm{OEt})$ $\mathrm{H}$ with various alkyl halides. Under otherwise identical conditions, a clear erosion in yield is observed as the reactivity of the electrophile decreases. ${ }^{31} \mathrm{P}-\mathrm{NMR}$ analysis of these reaction mixtures indicate the formation of $\mathrm{PhP}(\mathrm{O})(\mathrm{OEt}) \mathrm{OLi}(\delta 17.2 \mathrm{ppm})$, along with the $\mathrm{P}(\mathrm{III})$ anion $\mathrm{PhP}(\mathrm{OEt})(\mathrm{OLi})(\delta 149 \mathrm{ppm})$, and the alkylation product $\mathrm{PhP}(\mathrm{O})(\mathrm{OEt}) \mathrm{Oct}(\delta 44.8 \mathrm{ppm})$. The low reactivity of the electrophile requires heating the reaction mixture during which competitive oxidation of the anion takes place, so a deoxygenation protocol was investigated. 5 Instead of a rigorous freeze-thaw-degass cycle, we opted for a simpler, more practical, deoxygenation method consisting of placing the reaction flask containing the $\mathrm{H}$-phosphinate ester and THF under vacuum for $5 \mathrm{~min}$ at $-78{ }^{\circ} \mathrm{C}$, and filling it with nitrogen prior to adding the other reagents. This moderate deoxygenation is sufficient to provide good alkylation yields with unreactive electrophiles ( $\mathrm{X}=\mathrm{Cl}$, OTs). To the best of our knowledge, this is the first example of successful alkylation with an alkyl chloride. Unlike primary iodides which are sufficiently reactive to not necessitate deoxygenation, isopropyl iodide behaves like $n$-octyl chloride and tosylate. This is also the first time a secondary halide is employed in the alkylation of a H-phosphinate.

The next stage in this study was to investigate the scope with respect to both H-phosphinate starting material and electrophile (Table 3).

As shown in Table 3, the general conditions can be successfully applied to a range of $\mathrm{H}$ phosphinate/electrophile pairs. The alkylation of the "Ciba-Geigy reagent" $\left(\mathrm{CH}_{3} \mathrm{C}(\mathrm{OEt})_{2} \mathrm{P}(\mathrm{O})\right.$ $(\mathrm{OEt}) \mathrm{H}) 6$ was examined in some detail (entries 1-9), in part because it is a representative $\mathrm{H}$ phosphinate ester, but also because the ketal group can be cleaved to unmask a $\mathrm{P}(\mathrm{O}) \mathrm{H}$ functional group (eq 3). ${ }^{7}$ While we ${ }^{8}$ and Gallagher 9 have reported the direct alkylation of phosphinates $\mathrm{ROP}(\mathrm{O}) \mathrm{H}_{2}$ under basic conditions which would provide the $\mathrm{H}$-phosphinate esters in one step (eq 4), the scope of this reaction is limited to reactive electrophiles, such as allylic halides, and it fails with most of the electrophiles used in Table 3.

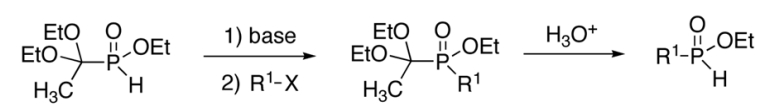

(3). 


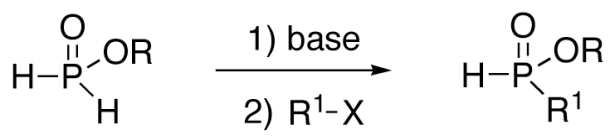

(4).

The H-phosphinate starting materials were generally available through our various methodologies (radical, Ni- and Pd- catalyzed hydrophosphinylations, or Pd-catalyzed crosscoupling). ${ }^{4}$ Various functional groups (esters, imides, carbamates) are tolerated under the reaction conditions (Table 3 ). This alkylation is comparable or superior to other conditions reported, ${ }^{1}$ especially because it proceeds with equimolar amounts of reagents. In the literature, an excess of reagent (electrophile or H-phosphinate) is often employed. ${ }^{1}$ For example, the product in Table 3, entry 2 was obtained in $42 \%$ yield, using $\mathrm{NaH}$ as the base. With halomethylpyridine hydrohalides (Table 3, entries 6 and 15), an equivalent of LiHMDS is employed prior to adding the electrophile to the lithium phosphinate solution. The products are precursors to GABA analogs, although none showed any significant activity on the GABA$\mathrm{B}$ receptor after appropriate deprotection steps. 10

Difluorochloromethane can be used to prepare the corresponding difluoromethylphosphinate. There was an example of such reaction in the literature although the product was not isolated. 11 We have extended this to several substrates (Table 3, entries 9, 10, 14). Our results concerning the reactivity of these compounds for the synthesis of fluorinated phosphinates will be reported shortly.

Epoxides also react satisfactorily in the presence of a stoichiometric amount of boron trifluoride etherate (Scheme 1). Products $\mathbf{1}$ and $\mathbf{2}$ are obtained as nearly 1:1 mixtures of diastereoisomers because the phosphorus atom is stereogenic. Although epoxide-openings have been reported using the silylation approach, we could not find any report of this reaction under basic conditions. 12

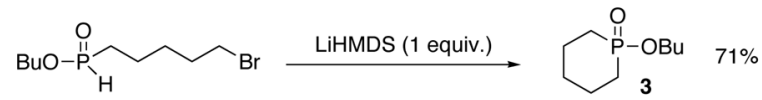

(5).

Equation 5 shows an example of an intramolecular alkylation to form P- heterocycle 3 (1butoxy-phosphinane-1-oxide).

The based-promoted alkylation can be applied to the synthesis of a variety of biologically active targets. For example, CGP 36742, 1c,13 a GABA-B antagonist which is currently undergoing Phase II clinical trials, can be synthesized easily using our radical-based hydrophosphinylation, 14 followed by our alkoxysilane-based esterification to form 4,15 and the present alkylation reaction to form intermediate 5. Debenzylation affords CGP $36742 \mathbf{6}$ cleanly without the need for cumbersome ion-exchange purification.

Another example is shown in Scheme 3 for the rapid synthesis of the known kynureninase inhibitor $\mathbf{8} .^{16}$ The key step forming 7 proceeds in good yield.

A similar strategy could be applied for the preparation of protected phosphinothricin (Scheme 4). ${ }^{17}$ The starting $\mathrm{H}$-phosphinate 9 was prepared using our recently disclosed alkylation of phosphinate esters. ${ }^{8}$ The base-promoted alkylation of 9 delivered protected phosphinothricin $\mathbf{1 0}$ in moderate yield. 


\section{Conclusion}

Our investigations of the base-promoted alkylation of H-phosphinate esters reveal that a standardized set of conditions can be established, using LiHMDS as the base and stoichiometric amounts of the reagents. A moderate, yet practical, deoxygenation protocol is necessary with less reactive electrophiles. A wide variety of $\mathrm{H}$-phosphinate esters can be alkylated, including the first successful examples with a primary alkyl chloride and a secondary alkyl iodide electrophiles. The reaction provides a viable alternative to the Arbuzov-like silylation methodology, and it can be applied to the synthesis of functionalized disubstituted phosphinate esters. The method should be useful to phosphorus chemistry practitioners, particularly because the stoichiometry allows the use of valuable moieties, present both in the phosphorus nucleophile and the carbon electrophile.

\section{Experimental Section}

\section{Typical Alkylation Procedure}

Neat alkyl H-phosphinate ester (1.0 eq., $1.5 \mathrm{mmol}$ ) was placed under vacuum in a dry twoneck flask, during $10 \mathrm{~min}$ before use. $5 \mathrm{ml}$ of anhydrous THF was then added under nitrogen. The flask was then placed at $-78^{\circ} \mathrm{C}$ and deoxygenated under vacuum for $5 \mathrm{~min}$. The reaction flask was back-filled with nitrogen and LiHMDS (1.0 M in THF, 1.0 eq., $1.5 \mathrm{mmol}$ ) was added at $-78^{\circ} \mathrm{C}$. After $15 \mathrm{~min}$, the electrophile ${ }^{*}\left(1 \mathrm{eq}, 1.5 \mathrm{mmol}\right.$ ) was added under $\mathrm{N}_{2}$ as a neat liquid, or as a $0.5 \mathrm{M}$ THF solution for solids. After the addition of the electrophile, the temperature of the solution was slowly allowed to warm to rt. ${ }^{* *}$ Once at rt, the reaction mixture was quenched with a satured solution of $\mathrm{NH}_{4} \mathrm{Cl} /$ brine, and extracted with ethyl acetate $(3 \mathrm{X})$ then dried over anhydrous $\mathrm{MgSO}_{4}$ and concentrated in vacuo. The resulting oil was purified by column chromatography over silica gel.

For alkyl iodides and alkyl triflate: 10 min at rt (except for the hindered iodides: reflux, $6 \mathrm{~h}$ )

For alkyl bromides: 2 to $4 \mathrm{~h}$ at $\mathrm{rt}$

For alkyl chlorides, and tosylates : reflux, $6 \mathrm{~h}$, or rt overnight (except for $\mathrm{BOMCl}: 10 \mathrm{~min}$ at rt).

For $\mathrm{HCF}_{2} \mathrm{Cl}$ the reaction mixture is warmed up and quenched at $0^{\circ} \mathrm{C}$.

\section{General procedure for alkyl chlorides and tosylates (Table 2, entry 6). Octyl-phenyl- phosphinic acid ethyl ester. ${ }^{18}$}

Neat ethyl phenyl-H-phosphinate $(0.510 \mathrm{~g}, 3 \mathrm{mmol})$ was placed under vacuum in a dry twoneck flask, during $10 \mathrm{~min}$ before use. Anhydrous THF $(10 \mathrm{~mL})$ was then added under nitrogen. The flask was placed at $-78^{\circ} \mathrm{C}$ and deoxygenated under vacuum for $5 \mathrm{~min}$. The reaction flask was back-filled with nitrogen and LiHMDS ( $1.0 \mathrm{M}$ in THF, $3 \mathrm{~mL}, 3 \mathrm{mmol})$ was added at $-78^{\circ}$ C. After $10 \mathrm{~min}, n$-octyl chloride $(510 \mu \mathrm{L}, 3 \mathrm{mmol})$ was added under $\mathrm{N}_{2}$. After addition, the reaction mixture was slowly allowed to warm up to rt. The solution was then refluxed overnight under $\mathrm{N}_{2}$. After cooling, the reaction mixture was quenched with $\mathrm{NH}_{4} \mathrm{Cl} /$ brine, and extracted with ethyl acetate $(3 \mathrm{X})$ then dried over anhydrous $\mathrm{MgSO}_{4}$ and concentrated in vacuo. The resulting oil was purified by column chromatography (silica, EtOAc:Hexanes 40:60) to afford the desired product (51\%). RN : [119079-17-3] ${ }^{1} \mathrm{H}$ NMR $\left(\mathrm{CDCl}_{3}, 300 \mathrm{MHz}\right) \delta 0.85$ (t, $J=6.7$

\footnotetext{
* In the case of the bromomethyl- or chloromethylpyridine hydrobromide or chloride, the pyridine was first deprotonated at $-78 \mathrm{C}$ in dry THF with LiHMDS (1 eq.) under $\mathrm{N}_{2}$ for 15 min, then added to the solution of the lithium phosphinate.

*** The temperature and reaction time after the solution reaches $\mathrm{rt}$ depend on the reactivity of the electrophile.
} 
$\mathrm{Hz}, 3 \mathrm{H}), 1.22-1.35(\mathrm{~m}, 10 \mathrm{H}), 1.29(\mathrm{t}, J=7.0 \mathrm{~Hz}, 3 \mathrm{H}), 1.46-1.60$ (m, $2 \mathrm{H}), 1.81-2.04(\mathrm{~m}, 2$ H), 4.84 \& 4.08 (m, 2 H), 7.45-7.60 (m, 3 H), 7.76-7.85 (m, 2 H).

\section{General procedure for alkyl bromides (Table 2, entry 4)}

Neat ethyl phenyl-H-phosphinate $(0.510 \mathrm{~g}, 3 \mathrm{mmol})$ was placed under vacuum in a dry twoneck flask, during $10 \mathrm{~min}$ before use. Anhydrous THF $(10 \mathrm{~mL})$ was then added under nitrogen. The flask was placed at $-78^{\circ} \mathrm{C}$ and deoxygenated under vacuum for $5 \mathrm{~min}$. The reaction flask was back-filled with nitrogen and LiHMDS ( $1.0 \mathrm{M}$ in THF, $3 \mathrm{~mL}, 3 \mathrm{mmol})$ was added at $-78^{\circ}$ C. After $10 \mathrm{~min}, n$-octyl bromide $(520 \mu \mathrm{L}, 3 \mathrm{mmol})$ was added under $\mathrm{N}_{2}$. After addition, the temperature of the solution was slowly allowed to warm to rt. After $3 \mathrm{~h}$ at $\mathrm{rt}$, the reaction mixture was quenched with $\mathrm{NH}_{4} \mathrm{Cl} /$ brine, and extracted with ethyl acetate $(3 \mathrm{X})$ then dried over anhydrous $\mathrm{MgSO}_{4}$ and concentrated in vacuo. The resulting oil was purified by column chromatography (silica, EtOAc:Hexanes 40:60) to afford octyl-phenyl-phosphinic acid ethyl ester in $71 \%$.

\section{General procedure for alkyl iodides and triflates (Table 3, entry 8 ). [(1,1-Diethoxy-ethyl)- ethoxy-phosphinoylmethyl]-phosphonic acid diethyl ester. ${ }^{19}$}

Neat ethyl (1,l-diethoxyethyl)phosphinate $(630 \mathrm{mg}, 3 \mathrm{mmol})$ was placed under vacuum in a dry two-neck flask, during $10 \mathrm{~min}$ before use. Anhydrous THF $(10 \mathrm{~mL})$ was then added under nitrogen. The flask was placed at $-78^{\circ} \mathrm{C}$ and deoxygenated under vacuum for $5 \mathrm{~min}$. The reaction flask was backfilled with nitrogen and LiHMDS (1.0 M in THF, $3 \mathrm{~mL}, 3 \mathrm{mmol})$ was added at $-78^{\circ} \mathrm{C}$. After $10 \mathrm{~min}$, alkyl triflate $(0.945 \mathrm{~g}, 3.15 \mathrm{mmol})$ dissolved in THF $(6 \mathrm{~mL})$ was added under $\mathrm{N}_{2}$. After addition, the temperature of the solution was slowly allowed to warm to rt. After 1 hour at rt, the reaction mixture was quenched with $\mathrm{NH}_{4} \mathrm{Cl} /$ brine, and extracted with ethyl acetate $(3 \mathrm{X})$ then dried over anhydrous $\mathrm{MgSO}_{4}$ and concentrated in vacuo. The resulting oil was purified by column chromatography (silica, EtOAc:MeOH 95:5) to afford the desired product (81\%). $\mathrm{RN}:[179015-83-9] .{ }^{1} \mathrm{H}$ NMR $\left(\mathrm{CDCl}_{3}, 300 \mathrm{MHz}\right) \delta 1.20 \& 1.21$ $(2 \times t, J=7.0 \mathrm{~Hz}, 6 \mathrm{H}), 1.34(\mathrm{~m}, 9 \mathrm{H}), 1.53\left(\mathrm{~d}, J_{\mathrm{HP}}=12.6 \mathrm{~Hz}, 3 \mathrm{H}\right), 2.41\left(\mathrm{ddd}, J_{\mathrm{HP}}=20.8 \mathrm{~Hz}\right.$, $\left.J_{\mathrm{HP}}=14.4 \mathrm{~Hz}, J=15.2 \mathrm{~Hz}, 1 \mathrm{H}\right), 2.68\left(\mathrm{ddd}, J_{\mathrm{HP}}=21.7 \mathrm{~Hz}, J_{\mathrm{HP}}=12.9 \mathrm{~Hz}, J=15.2 \mathrm{~Hz}, 1 \mathrm{H}\right)$, 3.61-3.78 (m, $5 \mathrm{H}), 4.08-4.41(\mathrm{~m}, 5 \mathrm{H}) .{ }^{31} \mathrm{P}$ NMR $\left(\mathrm{CDCl}_{3}, 121.47 \mathrm{MHz}\right) \delta 22.1 \& 40.09(2 \times \mathrm{d}$, $\left.J_{\mathrm{PP}}=20.0 \mathrm{~Hz}\right)$.

\section{Representative procedure for hindered iodides (Table 2, entry 8 ). Isopropyl-phenyl- phosphinic acid ethyl ester. 20}

Neat ethyl phenyl-H-phosphinate (510 $\mathrm{mg}, 3 \mathrm{mmol}$ ) was placed under vacuum in a dry twoneck flask, during $10 \mathrm{~min}$ before use. Anhydrous THF $(10 \mathrm{~mL})$ was then added under nitrogen. The flask was placed at $-78^{\circ} \mathrm{C}$ and deoxygenated under vacuum for $5 \mathrm{~min}$. The reaction flask was back-filled with nitrogen and LiHMDS ( $1.0 \mathrm{M}$ in THF, $3 \mathrm{~mL}, 3 \mathrm{mmol})$ was added at $-78^{\circ}$ C. After $10 \mathrm{~min}$, isopropyl iodide ( $300 \mu \mathrm{L}, 3 \mathrm{mmol}$ ) was added under $\mathrm{N}_{2}$. After addition, the temperature of the solution was slowly allowed to warm to rt. The solution was then refluxed for 6 hours. After cooling, the reaction mixture was quenched with $\mathrm{NH}_{4} \mathrm{Cl} /$ brine, and extracted with ethyl acetate $(3 \mathrm{X})$ then dried over anhydrous $\mathrm{MgSO}_{4}$ and concentrated in vacuo. The resulting oil was purified by column chromatography (silica, EtOAc:Hexanes 80:20) to afford the desired product (45\%). RN : [53716-14-6]. ${ }^{1} \mathrm{H}$ NMR $\left(\mathrm{CDCl}_{3}, 300 \mathrm{MHz}\right) \delta 1.04(\mathrm{~d}, J=7.0$ $\mathrm{Hz}, 1.5 \mathrm{H}), 1.10(\mathrm{~d}, J=7.0 \mathrm{~Hz}, 1.5 \mathrm{H}), 1.16(\mathrm{~d}, J=7.0 \mathrm{~Hz}, 1.5 \mathrm{H}), 1.22(\mathrm{~d}, J=7.0 \mathrm{~Hz}, 1.5 \mathrm{H})$, $1.32(\mathrm{t}, J=7 \mathrm{~Hz}, 3 \mathrm{H}), 2.0-2.15(\mathrm{~m}, 1 \mathrm{H}), 3.80-3.95(\mathrm{~m}, 1 \mathrm{H}), 4.05-4.20(\mathrm{~m}, 1 \mathrm{H}), 7.45-7.60$ $(\mathrm{m}, 3 \mathrm{H}), 7.70-7.80(\mathrm{~m}, 2 \mathrm{H}) .{ }^{31} \mathrm{P} \mathrm{NMR}\left(\mathrm{CDCl}_{3}, 121.47 \mathrm{MHz}\right) \delta 54.60(\mathrm{~s})$. 


\section{Representative procedure with pyridinium salts (Table 3, entry 6b). (1,1-Diethoxy-ethyl)- pyridin-3-ylmethyl-phosphinic acid ethyl ester}

Neat ethyl (1,1-diethoxyethyl)phosphinate $(0.630 \mathrm{~g}, 3 \mathrm{mmol})$ was placed under vacuum in a dry two-neck flask, during $10 \mathrm{~min}$ before use. Anhydrous THF $(10 \mathrm{~mL})$ was then added under nitrogen. The flask was placed at $-78^{\circ} \mathrm{C}$ and deoxygenated under vacuum for $5 \mathrm{~min}$. The reaction flask was back-filled with nitrogen and LiHMDS (1.0 M in THF, $3 \mathrm{~mL}, 3 \mathrm{mmol}$ ) was added at $-78^{\circ} \mathrm{C}$. In a second dry two-neck flask, LiHMDS (1.0 M in THF, $\left.3 \mathrm{~mL}, 3 \mathrm{mmol}\right)$ was added to a solution of 2-(bromomethyl)pyridine hydrobromide $(0.759 \mathrm{~g}, 3 \mathrm{mmol})$ in anhydrous THF ( $5 \mathrm{~mL}$ ), at $-78^{\circ} \mathrm{C}$ under $\mathrm{N}_{2}$. After $10 \mathrm{~min}$, the first solution was added to second one. After $10 \mathrm{~min}$ at $-78^{\circ} \mathrm{C}$, the temperature of the solution was slowly allowed to warm to rt. After 3 hours at $\mathrm{rt}$, the reaction mixture was quenched with $\mathrm{NH}_{4} \mathrm{Cl} / \mathrm{brine}$, and extracted with ethyl acetate $(3 \mathrm{X})$ then dried over anhydrous $\mathrm{MgSO}_{4}$ and concentrated in vacuo. The resulting oil was purified by column chromatography (silica, EtOAc 100\%) to afford the desired product $(60 \%) .{ }^{1} \mathrm{H} \mathrm{NMR}\left(\mathrm{CDCl}_{3}, 300 \mathrm{MHz}\right) \delta 1.12-1.29(\mathrm{~m}, 9 \mathrm{H}), 1.50\left(\mathrm{~d}, J_{\mathrm{HP}}=11.4 \mathrm{~Hz}, 3 \mathrm{H}\right), 3.11$ \& 3.23 (ABXsyst, $\left.J_{\mathrm{AB}}=14.6 \mathrm{~Hz}, J_{\mathrm{BX}}=8.2 \mathrm{~Hz}, J_{\mathrm{AX}}=8.6 \mathrm{~Hz}, 2 \mathrm{H}\right), 3.58-3.88(\mathrm{~m}, 4 \mathrm{H}), 4.08$ $(\mathrm{qt}, J=7.3 \mathrm{~Hz}, 2 \mathrm{H}), 7.25(\mathrm{dd}, J=7.9 \mathrm{~Hz}, J=3.5 \mathrm{~Hz}, 1 \mathrm{H}), 7.67-7.74(\mathrm{~m}, 1 \mathrm{H}), 8.48-8.51(\mathrm{~m}$, $2 \mathrm{H}) .{ }^{13} \mathrm{C}\left\{{ }^{1} \mathrm{H}\right\} \mathrm{NMR}\left(\mathrm{CDCl}_{3}, 75.45 \mathrm{MHz}\right) \delta 15.6\left(\mathrm{~d}, J_{\mathrm{POCC}}=20.7 \mathrm{~Hz}\right), 16.7\left(\mathrm{~d}, J_{\mathrm{PCC}}=5.2\right.$ $\mathrm{Hz}), 20.6\left(\mathrm{~d}, J_{\mathrm{POCC}}=12.4 \mathrm{~Hz}\right), 30.0\left(\mathrm{~d}, J_{\mathrm{PC}}=78 \mathrm{~Hz}\right), 57.9\left(\mathrm{~d}, J_{\mathrm{POC}}=7.8 \mathrm{~Hz}\right), 58.7(\mathrm{~d}$,

$\left.J_{\mathrm{POC}}=4.6 \mathrm{~Hz}\right), 62.3\left(\mathrm{~d}, J_{\mathrm{POC}}=6.9 \mathrm{~Hz}\right), 101.5\left(\mathrm{~d}, J_{\mathrm{PC}}=142 \mathrm{~Hz}\right), 123.4,127.3\left(\mathrm{~d}, J_{\mathrm{PCC}}=8.3\right.$ $\mathrm{Hz}), 137.8\left(\mathrm{~d}, J_{\mathrm{PCCCC}}=4.6 \mathrm{~Hz}\right), 148.2\left(\mathrm{~d}, J_{\mathrm{PCCC}}=3.2 \mathrm{~Hz}\right), 151.1\left(\mathrm{~d}, J_{\mathrm{PCCCC}}=6.0 \mathrm{~Hz}\right) .{ }^{31} \mathrm{P}$ $\operatorname{NMR}\left(\mathrm{CDCl}_{3}, 121.47 \mathrm{MHz}\right) \delta 44.21$ (s). HRMS ( $\mathrm{M}^{+} \mathrm{H}$ ion by direct probe) : calc. for $\mathrm{C}_{14} \mathrm{H}_{25} \mathrm{O}_{4} \mathrm{P} 302.1521$, obs. 302.1526.

\section{Representative procedure with epoxides (Scheme 1). (2 - Hydroxy -hex-5-enyl)-phenyl- phosphinic acid ethyl ester 2}

Neat ethyl phenyl-H-phosphinate $(0.510 \mathrm{mg}, 3 \mathrm{mmol})$ was placed under vacuum in a dry twoneck flask, during $10 \mathrm{~min}$ before use. Anhydrous THF $(10 \mathrm{~mL})$ was then added under nitrogen. The flask was placed at $-78^{\circ} \mathrm{C}$ and deoxygenated under vacuum for $5 \mathrm{~min}$. The reaction flask was back-filled with nitrogen and LiHMDS ( $1.0 \mathrm{M}$ in THF, $3 \mathrm{~mL}, 3 \mathrm{mmol})$ was added at $-78^{\circ}$ C. After $10 \mathrm{~min}, 1,2$-epoxy-5-hexene $(340 \mu \mathrm{L}, 3 \mathrm{mmol})$ was added followed by the addition of boron trifluoride etherate $(380 \mu \mathrm{L}, 3 \mathrm{mmol})$, under $\mathrm{N}_{2}$. After addition, the temperature of the solution was slowly allowed to warm to rt. After 2 hours at rt, the reaction mixture was quenched with $\mathrm{NH}_{4} \mathrm{Cl} /$ brine, and extracted with ethyl acetate $(3 \mathrm{X})$ then dried over anhydrous $\mathrm{MgSO}_{4}$ and concentrated in vacuo. The resulting oil was purified by column chromatography (silica, EtOAc $100 \%)$ to afford the desired product $(85 \%) .{ }^{1} \mathrm{H} \mathrm{NMR}\left(\mathrm{CDCl}_{3}, 300 \mathrm{MHz}\right) \delta 1.31$ $(\mathrm{t}, J=7.0 \mathrm{~Hz}, 3 \mathrm{H}), 1.53-1.72(\mathrm{~m}, 2 \mathrm{H}), 1.91-2.19(\mathrm{~m}, 5 \mathrm{H}), 3.87(\mathrm{~m}, 1 \mathrm{H}), 4.07-4.23(\mathrm{~m}, 2$ $\mathrm{H}), 4.88-5.06(\mathrm{~m}, 2 \mathrm{H}), 5.78(\mathrm{tqd}, J=6.4 \mathrm{~Hz}, J=10.5 \mathrm{~Hz}, 1 \mathrm{H}), 7.46-7.83(\mathrm{~m}, 5 \mathrm{H}) .{ }^{13} \mathrm{C}$ $\left\{{ }^{1} \mathrm{H}\right\} \mathrm{NMR}\left(\mathrm{CDCl}_{3}, 75.45 \mathrm{MHz}\right) \delta 16.7\left(\mathrm{~d}, J_{\mathrm{POCC}}=6.6 \mathrm{~Hz}\right), 29.82,36.2,37.2\left(\mathrm{~d}, J_{\mathrm{PC}}=84.9\right.$ $\mathrm{Hz}), 37.5\left(\mathrm{~d}, J_{\mathrm{PCCCC}}=3.5 \mathrm{~Hz}\right), 37.6\left(\mathrm{~d}, J_{\mathrm{PCCCC}}=3.2 \mathrm{~Hz}\right), 61.1\left(\mathrm{~d}, J_{\mathrm{POCC}}=6.9 \mathrm{~Hz}\right), 61.2(\mathrm{~d}$, $\left.J_{\mathrm{POCC}}=6.6 \mathrm{~Hz}\right), 65.6,66.4\left(\mathrm{~d}, J_{\mathrm{POCC}}=6.0 \mathrm{~Hz}\right), 128.9\left(\mathrm{~d}, J_{\mathrm{PCC}}=2.3 \mathrm{~Hz}\right), 129.1\left(\mathrm{~d}, J_{\mathrm{PCC}}=\right.$ $2.0 \mathrm{~Hz}), 130.4\left(\mathrm{~d}, J_{\mathrm{PC}}=128 \mathrm{~Hz}\right), 131.5\left(\mathrm{~d}, J_{\mathrm{PCCC}}=10.4 \mathrm{~Hz}\right), 131.8\left(\mathrm{~d}, J_{\mathrm{PCCC}}=10.1 \mathrm{~Hz}\right)$, $132.1,132.8,132.9,138.2\left(\mathrm{~d}, J_{\mathrm{PCCCC}}=5.5 \mathrm{~Hz}\right) .{ }^{31} \mathrm{P} \mathrm{NMR}\left(\mathrm{CDCl}_{3}, 121.47 \mathrm{MHz}\right) \delta 44.26(\mathrm{~s})$, 55.74 (s). HRMS $\left(\mathrm{EI}^{+}\right)$: calc. for $\mathrm{C}_{14} \mathrm{H}_{21} \mathrm{O}_{3} \mathrm{P} 268.1228$, obs. 268.1228 .

\section{Representative procedure with freon (Table 3, entry 9 ). Difluoromethyl-(1,1-diethoxy-ethyl)- phosphinic acid ethyl ester. ${ }^{1 d}$}

Neat ethyl (1,1-diethoxyethyl)phosphinate $(12.0 \mathrm{~g}, 57.1 \mathrm{mmol})$ was placed under vacuum in a dry two-neck flask equipped with a cold finger, during $10 \mathrm{~min}$ before use. Anhydrous THF ( 80 $\mathrm{mL}$ ) was then added under $\mathrm{N}_{2}$. The flask was cooled to $-78^{\circ} \mathrm{C}$ and deoxygenated under vacuum for $5 \mathrm{~min}$. The reaction flask was back-filled with nitrogen, then LiHMDS (1.0 M in THF, 57.1 $\mathrm{mL}, 57.1 \mathrm{mmol}$ ) was added at $-78^{\circ} \mathrm{C}$. After $15 \mathrm{~min}$, condensed chlorodifluoromethane (around 
$5.0 \mathrm{~g}, 58.0 \mathrm{mmol}$ ) was added under $\mathrm{N}_{2}$. After addition, the temperature of the solution was kept at $-78^{\circ} \mathrm{C}$ during $10 \mathrm{~min}$, then slowly allowed to warm to $0^{\circ} \mathrm{C}$. After $10 \mathrm{~min}$ at $0^{\circ} \mathrm{C}$, the reaction mixture was quenched with a saturated solution of $\mathrm{NH}_{4} \mathrm{Cl} /$ brine, and extracted with EtOAc $(3 \mathrm{X})$ then dried over anhydrous $\mathrm{MgSO}_{4}$. Concentration in vacuo gave an oil which was purified by column chromatography (silica, EtOAc:Hexanes 30:70) to afford the desired product (71\%). RN : [139474-89-8]. ${ }^{1} \mathrm{H}$ NMR $\left(\mathrm{CDCl}_{3}, 300 \mathrm{MHz}\right) \delta 1.22(\mathrm{t}, J=7.0 \mathrm{~Hz}, 6 \mathrm{H})$, $1.39(\mathrm{t}, J=7.0 \mathrm{~Hz}, 3 \mathrm{H}), 1.58\left(\mathrm{~d}, J_{\mathrm{HP}}=12.0 \mathrm{~Hz}, 3 \mathrm{H}\right), 3.63-3.87(\mathrm{~m}, 4 \mathrm{H}), 4.29-4.39(\mathrm{~m}, 2$ $\mathrm{H}), 6.08\left(\mathrm{dt}, J_{\mathrm{HF}}=27.5 \mathrm{~Hz}, J_{\mathrm{HF}}=48.9 \mathrm{~Hz}, 1 \mathrm{H}\right) .{ }^{31} \mathrm{P} \mathrm{NMR}\left(\mathrm{CDCl}_{3}, 121.47 \mathrm{MHz}\right) \delta 27.5(\mathrm{t}$, $\left.J_{\mathrm{FP}}=71.4 \mathrm{~Hz}\right) .19 \mathrm{~F} \mathrm{NMR}\left(\mathrm{CDCl}_{3}, 282.30 \mathrm{MHz}\right) \delta-135.31\left(\mathrm{ddt}, J_{\mathrm{FH}}=21.8 \mathrm{~Hz}, J_{\mathrm{FP}}=71.4\right.$ $\left.\mathrm{Hz}, J_{\mathrm{FH}}=49.5 \mathrm{~Hz}\right)$.

\section{Supplementary Material}

Refer to Web version on PubMed Central for supplementary material.

\section{Acknowledgements}

The National Institute of General Medical Sciences/NIH (R01 GM067610) is gratefully acknowledged for financial support. JLM thanks Gerry Katchinska for a generous gift of $\mathrm{CF}_{2} \mathrm{HCl}$, and Dr. Laëtitia Coudray for helpful discussions.

\section{References}

1. Base-promoted alkylations of H-phosphinate esters: (a) Baillie AC, Cornell CL, Wright BJ, Wright K. Tetrahedron Lett 1992;33:5133.NaH (b) Baylis EK. Tetrahedron Lett 1995;36:9385.(Na) (c) Froestl W, Mickel SJ, von Sprecher G, Diel PJ, Hall RG, Maier L, Strub D, Melillo V, Baumann PA, Bernasconi R, Gentsch C, Hauser K, Jaekel J, Karlsson G, Klebs K, Maitre L, Marescaux C, Pozza MF, Schmutz M, Steinmann MW, van Riezen H, Vassout A, Mondadori C, Olpe HR, Waldmeier PC, Bittiger H. J Med Chem 1995;38:3313. [PubMed: 7650685](NaH, BuLi) (d) Froestl W, Mickel SJ, Hall RG, von Sprecher G, Diel PJ, Strub D, Baumann PA, Brugger F, Gentsch C, Jaekel J, Olpe HR, Rihs G, Vassout A, Waldmeier PC, Bittiger H. J Med Chem 1995;38:3297. [PubMed: 7650684](NaH) (e) Magnin DR, Biller SA, Dickson JK Jr, Logan JV, Lawrence RM, Chen Y, Sulsky RB, Ciosek CP Jr, Harrity TW, Jolibois KG, Kunselman LK, Rich LC, Slusarchyk DA. J Med Chem 1995;38:2596. [PubMed: 7629799](NaHMDS) (f) Gallagher MJ, Ranasinghe MG, Jenkins ID. Phosphorus, Sulfur, Silicon 1996;115:255.(i-PrONa) (g) Fairhurst RA, Collingwood SP, Lambert D, Taylor RJ. Synlett 2001:467.(KHMDS) (h) Larenco C, Villien L, Kaufmann G. Tetrahedron 1984;40:2731.(NaH) (i) McKittrick BA, Stamford AW, Weng X, Ma K, Chackalamannil S, Czarniecki M, Cleven RM, Fawzi AB. Bioorg Med Chem Lett 1996;6:1629.(NaH, LDA) (j) Froestl W, Bettler B, Bittiger H, Heid J, Kaupmann K, Mickel SJ, Strub D. Il Farmaco 2003;58:173. [PubMed: 12620413](NaH) (k) Kehler J, Ebert B, Dahl O, Krogsgaard-Larsen P. Tetrahedron 1999;55:771.(LDA, t-BuOK) (1) Hemmi K, Takeno H, Hashimoto M, Kamiya T. Chem Pharm Bull 1982;30:111. [PubMed: 7083400](BuLi) (m) Lindell SD, Turner RM. Tetrahedron Lett 1990;31:5381.(NaH) (n) Gallagher MJ, Honegger H. Tetrahedron Lett 1977:2987.(MeONa) (o) Hall RG, Kane PD, Bittiger H, Froestl W. J Label Compounds Radiopharm 1995:129.

2. For some representative examples of the silicon method, see: (a) Boyd EA, Regan AC, James K. Synthesis of Alkyl Phosphinic Acids from Silyl Phosphonites and Alkyl Halides. Tetrahedron Lett 1994;35:4223. (b) Boyd EA, Corless M, James K, Regan AC. A Versatile Route to Substituted Phosphinic Acids. Tetrahedron Lett 1990;31:2933. (c) Malachowski WP, Coward JK. J Org Chem 1994;59:7625. (d) Reck F, Marmor S, Fisher S, Wuonola MA. Bioorg Med Chem Lett 2001;11:1451. [PubMed: 11378375] (e) Ribière P, Altamirano-Bravo K, Antczak MI, Hawkins JD, Montchamp JL. J Org Chem 2005;70:4064. [PubMed: 15876098] See also references 1c, 1d, 1h

3. Representative examples: (a) Grembecka J, Mucha A, Cierpicki T, Kafarski P. J Med Chem 2003;46:2641. [PubMed: 12801228] (b) Lloyd J, Schmidt JB, Hunt JT, Barrish JC, Little DK, Tymiak AA. Bioorg Med Chem Lett 1996;6:1323. (c) Karanewsky DS, Badia MC, Cushman DW, DeForrest JM, Dejneka T, Loots MJ, Perri MG, Petrillo EW Jr, Powell JR. J Med Chem 1988;31:204. [PubMed: 3336020] (d) Qiao L, Nan F, Kunkel M, Gallegos A, Powis G, Kozikowski AP. J Med Chem 1998;41:3303. [PubMed: 9719581] (e) Tokutake N, Hiratake J, Katoh M, Irie T, Kato H, Oda J. Bioorg 
Med Chem 1998;6:1935. [PubMed: 9839023] (f) Manthey MK, Huang DTC, Bubb WA, Christopherson RI. J Med Chem 1998;41:4550. [PubMed: 9804694] (g) Ebetino FH, Berk JD. J Organomet Chem 1997;529:135. (h) Vayron P, Renard PY, Valleix A, Mioskowski C. Chem Eur J 2000;6:1050. (i) Jackson PF, Cole DC, Slusher BS, Stetz SL, Ross LE, Donzati BA, Trainor DA. J Med Chem 1996;39:619. [PubMed: 8558536] (j) Hiratake J. Chemical Record 2005;5:209. [PubMed: 16041744] (k) Bartley DM, Coward JK. J Org Chem 2005;70:6757. [PubMed: 16095295] (l) Valiaeva N, Bartley D, Konno T, Coward JK. J Org Chem 2001;66:5146. [PubMed: 11463268] (m) Jackson PF, Tays KL, Maclin KM, Ko YS, Li W, Vitharana D, Tsukamoto T, Stoermer D, Lu XCM, Wozniak K, Slusher BS. J Med Chem 2001;44:4170. [PubMed: 11708918] (n) Collinsova M, Jiracek J. Curr Med Chem 2000;7:629. [PubMed: 10702630] (o) Flohr A, Aemissegger A, Hilvert D. J Med Chem 1999;42:2633. [PubMed: 10411483] (p) Chen S, Coward JK. J Org Chem 1998;63:502. [PubMed: 11672038] (q) Hiratake J, Kato H, Oda J-i. J Am Chem Soc 1994;116:12059.

4. Reviews: (a) Montchamp JL. J Organomet Chem 2005;690:2388. (b) Montchamp JL. Specialty Chemicals Magazine 2006;26:44.

5. Other workers have used deoxygenation previously, see ref. $1 \mathrm{k}$.

6. For applications of the "Ciba-Geigy reagents", see: (a) Dingwall JG, Ehrenfreund J, Hall RG, Jack J. Phosphorus Sulfur 1987;30:571. (b) McCleery PP, Tuck B. J Chem Soc Perkin Trans I 1989:1319. (c) Dingwall JG, Ehrenfreund J, Hall RG. Tetrahedron 1989;45:3787. (d) Baylis EK. Tetrahedron Lett 1995;36:9385. (e) Baylis EK. Tetrahedron Lett 1995;36:9389. (f) Bennett SNL, Hall RG. J Chem Soc Trans 1 1995:1145. See also refs 1c and 1d

7. Cleavage of ketal protecting group to H-phosphinate: see ref. 6.

8. Abrunhosa-Thomas I, Ribière P, Adcock AC, Montchamp JL. Synthesis 2006;2:325.

9. Gallagher MJ, Ranasinghe MG, Jenkins ID. Phosphorus, Sulfur, Silicon 1996;115:255.

10. The compounds were inactive.

11. $\mathrm{CH}_{3} \mathrm{C}(\mathrm{OEt})_{2} \mathrm{P}(\mathrm{O})(\mathrm{OEt}) \mathrm{CF}_{2} \mathrm{H}$ has been prepared in $95 \%$ yield using $\mathrm{NaH}$, and was used in situ: see ref $1 \mathrm{c}$. The synthetic use of this and other difluorophosphinates described herein will be reported separately.

12. For examples of epoxide-opening using the silicon method, see: refs $1 \mathrm{c}, 1 \mathrm{k}$.

13. CGP36742/SGS742: (a) Chebib M, Vandenberg RJ, Froestl W, Johnston GAR. Eur J Pharmacol 1997;329:223. [PubMed: 9226416] (b) Pittaluga A, Vaccari D, Raiteri M. J Pharmacol Exp Ther 1997;283:82. [PubMed: 9336311] (c) Steulet AF, Moebius HJ, Mickel SJ, Stoecklin K, Waldmeier PC. Biochem Pharmacol 1996;51:613. [PubMed: 8615897]

14. Deprèle S, Montchamp JL. J Org Chem 2001;66:6745. [PubMed: 11578230]

15. Dumond YR, Baker RL, Montchamp JL. Org Lett 2000;2:3341. [PubMed: 11029205]

16. Ross FC, Botting NP, Leeson PD. Bioorg Med Chem Lett 1996;6:2643.

17. (a) Zeiss HG. J Org Chem 1991;56:1783. (b) Maier L, Rist G. Phosphorus, Sulfur 1983;17:21. (c) Tan S, Evans R, Singh B. Amino Acids 2006;30:195. [PubMed: 16547651] (d) Evstigneeva ZG, Solov'eva NA, Sidel'nikova LI. Appl Biochem Microbiol 2003;39:539.

18. Pudovik AN, Konovalova IV. J Gen Chem USSR 1960;30:2328.

19. Luke GP, Shakespeare WC. Synth Commun 2002;32:2951.

20. (a) Zymanczyk-Duda E, Lejczak B, Kafarski P. Phosphorus, Sulfur Silicon Relat Elem 1996;112:47. (b) Siddall TH III, Prohaska CA. J Am Chem Soc 1962;84:2502. 


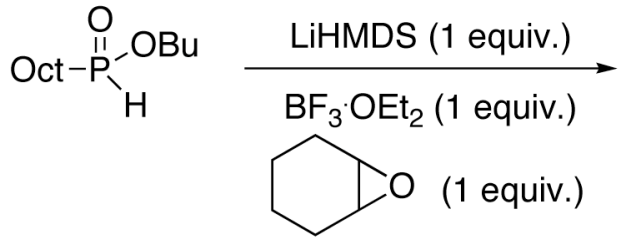<smiles>CCCCOP(=O)([O-])[C@H]1CCC[C@H](I)[C@@H]1O</smiles><smiles>CCOP(=O)(c1ccccc1)c1ccccc1</smiles><smiles>C=CCCC1(COCC)CO1</smiles><smiles>C=CCC[C@H](O)CP(=O)(OCC)c1ccccc1</smiles>
$85 \%$

Scheme 1.

Epoxide opening 


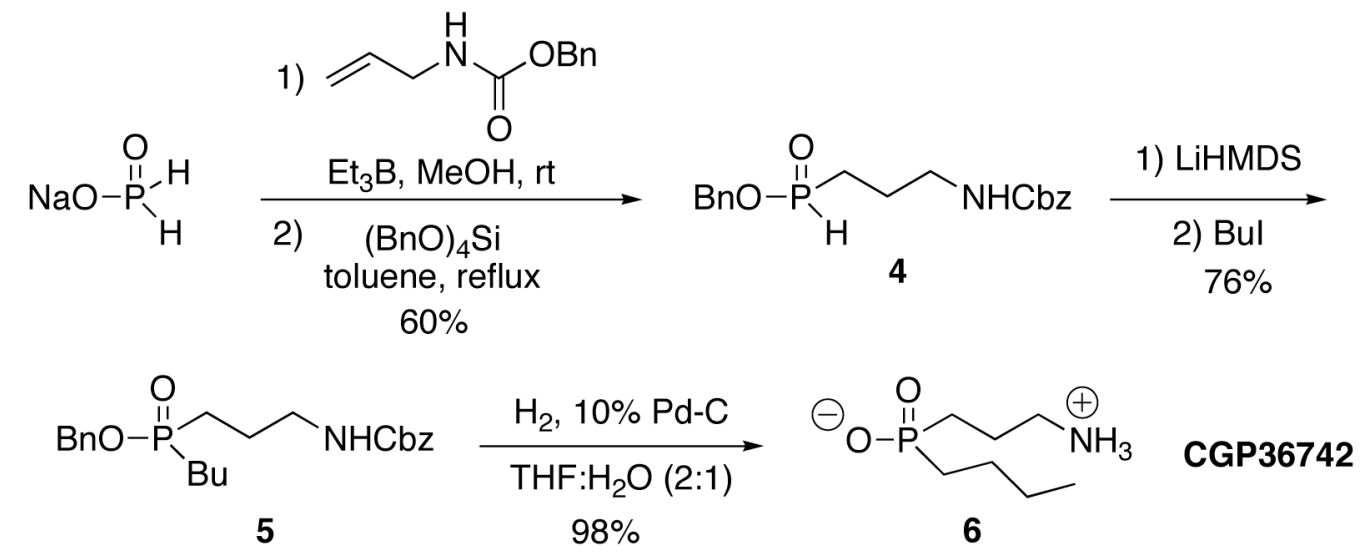

Scheme 2.

Synthesis of the GABA-B antagonist CGP 36742 


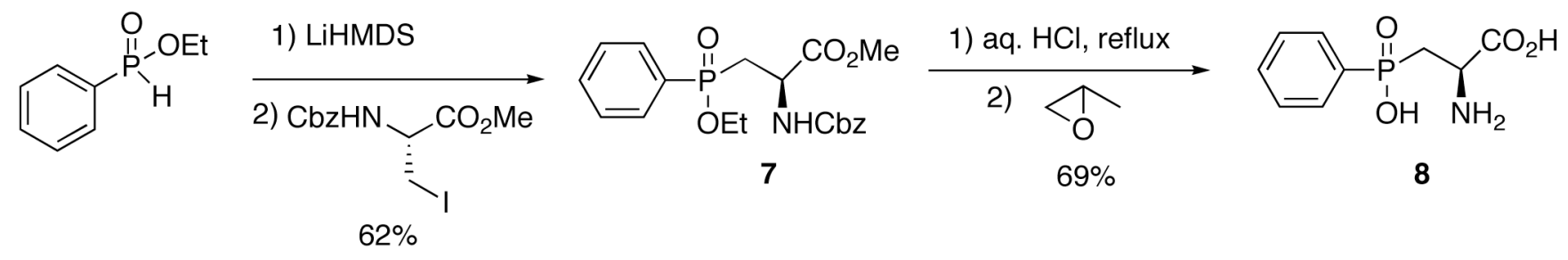

\section{Scheme 3.}

Synthesis of a known kynureninase inhibitor 


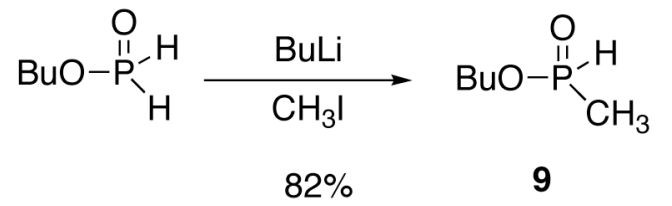

2)

1) LiHMDS

)<smiles>COC(=O)C(CCBr)NC(C)=O</smiles><smiles>CCCCC(NC(CCP(C)(=O)OCC)C(C)=O)C(C)=O</smiles>

$40 \%$

Scheme 4.

Synthesis of a phosphinothricin precursor 
Table 1

${ }^{a}$ Role of the base in the alkylation of butyl octyl-H-phosphinate with butyl iodide

\begin{tabular}{|c|c|c|c|c|}
\hline Entry & Substrate & Conditions & Base & NMR conversion $\% b$ \\
\hline 1 & $\mathrm{BuI}$ & $\mathrm{THF}, 0^{\circ} \mathrm{C}$ to $\mathrm{rt}$ & $\mathrm{Na}$ & 16 \\
\hline 2 & $\mathrm{BuI}$ & $\mathrm{THF},-78^{\circ} \mathrm{C}$ to $\mathrm{rt}$ & $i$-PrMgCl & 64 \\
\hline 3 & $\mathrm{BuI}$ & $\mathrm{THF},-78^{\circ} \mathrm{C}$ to $\mathrm{rt}$ & $\mathrm{MeLi}$ & 56 \\
\hline 4 & $\mathrm{BuI}$ & $\mathrm{THF},-78^{\circ} \mathrm{C}$ to $\mathrm{rt}$ & $\mathrm{BuLi}$ & 60 \\
\hline 5 & $\mathrm{BuI}$ & $\mathrm{THF},-78^{\circ} \mathrm{C}$ to $\mathrm{rt}$ & LDA & 89 \\
\hline 6 & $\mathrm{BuI}$ & $\mathrm{THF},-78^{\circ} \mathrm{C}$ to $\mathrm{rt}$ & LiHMDS & 100 \\
\hline
\end{tabular}

${ }^{a}$ All reactions were conducted in freshly distilled anhydrous THF, under $\mathrm{N}_{2}$.

${ }^{b}$ NMR conversion yields are determined by integration of all the resonances in the crude ${ }^{31} \mathrm{P}$ NMR spectra. investigate the influence of the electrophile 


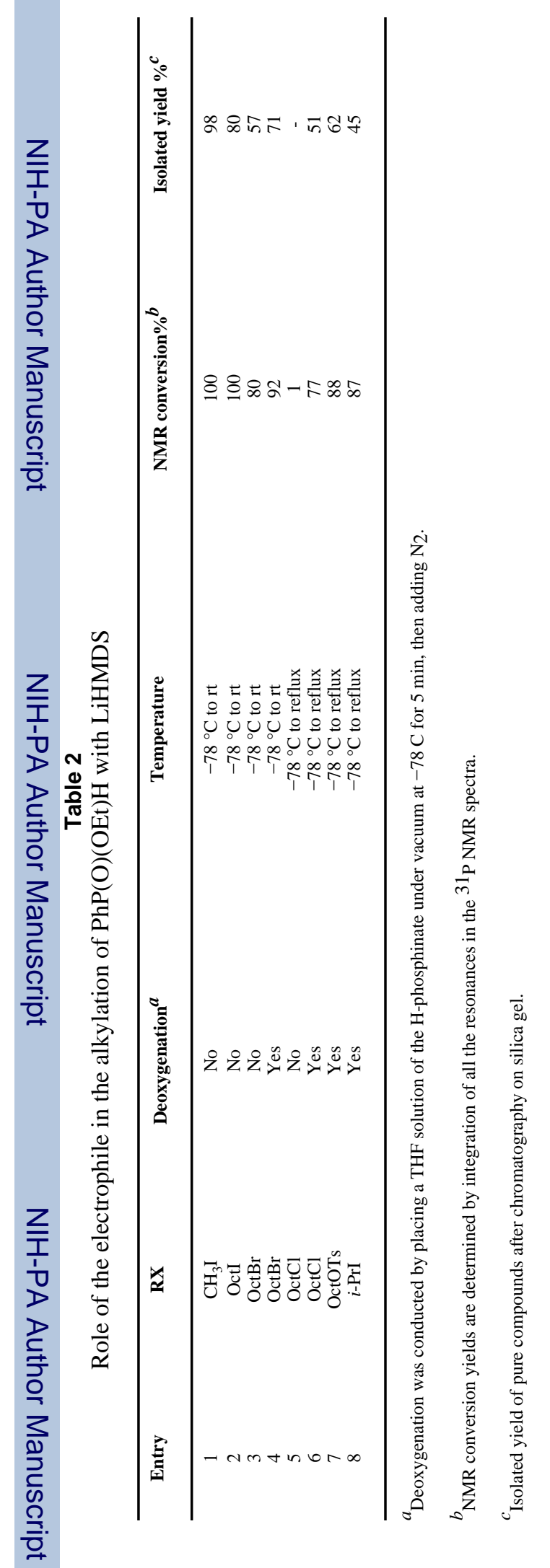


Table 3

Reaction Scope ${ }^{a}$

$\stackrel{\text { H- }}{\text { Phosphinate Ester }}$

Electrophile $^{b}$

Product

Isolated yield \%

\begin{tabular}{|c|c|}
\hline $\begin{array}{l}1 \mathrm{a} \\
1 \mathrm{~b}\end{array}$ & \\
\hline 2 & \\
\hline 3 & Eto \\
\hline
\end{tabular}

4<smiles>CCOC(C)(OCC)P(=O)=O</smiles><smiles>C=CCCCCBr</smiles>

EtO

$\mathrm{EtO}_{2} \mathrm{C} \smile \mathrm{Br}$<smiles>CCOC(=O)CCCP(=O)(OCC)C(C)(OCC)OCC</smiles><smiles>O=C1c2ccccc2C(=O)N1CBr</smiles>

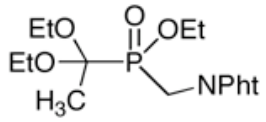<smiles>C=C(CBr)C(=O)OCC</smiles><smiles>C=C(CP(=O)(OCC)C(C)(OCC)OCC)OCC</smiles>

$5 \mathrm{a}$
$5 \mathrm{~b}$<smiles>CCOC(C)(OCC)P(=O)=O</smiles><smiles>[R]OCCl</smiles><smiles>CCOC(C)(OCC)P(=O)(CO)OCC</smiles><smiles>CCOC(C)(OCC)P(=O)=O</smiles><smiles>[X]c1cccnc1</smiles><smiles>CCOC(C)(OCC)P(=O)(OCC)C1C=NC=CC1</smiles><smiles>CCOC(C)(OCC)P(=O)=O</smiles>

8<smiles>CCOC(C)(OCC)P(=O)=O</smiles>

9<smiles>CCOC(C)(OCC)P(=O)=O</smiles>

10<smiles>CCOP(=O)(Cl)Cl</smiles>

11<smiles>CCCCOP(=O)([O-])OCC</smiles><smiles>O=C(NCCBr)OCc1ccccc1</smiles><smiles>CCOC(C)(OCC)P(=O)(CCNC(C)=O)OCC</smiles><smiles>CCOP(=O)(CO[Ga])OCC</smiles>

$\mathrm{F}_{2} \mathrm{CHCI}$

$i$-Prl<smiles>CCOC(C)(OCC)P(=O)(CP(=O)(OCC)OCC)OCC</smiles><smiles>CCOC(C)(OCC)P(=O)(OCC)C(F)(F)F</smiles><smiles>CCOP(=O)([O-])C(F)(F)F</smiles><smiles>CCOP(=O)([O-])C(C)C</smiles>

12<smiles>CCCCC(CCC)[P+]([O-])=CC(C)CC</smiles>

13<smiles>C=CCP(=O)(OCCC)OCCC</smiles><smiles>C=CCCCBr</smiles><smiles>C=CCCCP(=O)(OCCC)C(=CP)CCC</smiles>

$\mathrm{CH}_{3} \mathrm{I}$<smiles>C=CCP(C)(=O)OCCC</smiles>

$\mathrm{F}_{2} \mathrm{CHCL}$<smiles>CCCCOP(=O)(CCCC)C(C)C</smiles><smiles>CCCOP(=O)(C/C=C(\C)CC/C=C(\C)CCC=C(C)C)C(F)(F)C(F)(F)F</smiles> 


\begin{tabular}{|c|c|c|c|c|}
\hline Entry & $\begin{array}{c}\text { H- } \\
\text { Phosphinate Ester }\end{array}$ & Electrophile $^{b}$ & Product & $\underset{c}{\text { Isolated yield \% }}$ \\
\hline $\begin{array}{l}15 \mathrm{a} \\
15 \mathrm{~b} \\
15 \mathrm{c}\end{array}$ & & $\begin{array}{l}\mathrm{X}=\mathrm{Cl}, \mathrm{p} \\
\mathrm{X}=\mathrm{Br}, \mathrm{m} \\
\mathrm{X}=\mathrm{Br}, \mathrm{o}\end{array}$ & & $\begin{array}{l}50 \\
62 \\
68\end{array}$ \\
\hline
\end{tabular}

${ }^{a}$ Details are provided in the experimental section.

${ }^{b}$ Electrophiles which did not react successfully under a variety of conditions (excess of base, heating) include $\mathrm{CH}_{2} \mathrm{I}_{2},\left(\mathrm{CH}_{2} \mathrm{Br}\right)_{2}$, bromoacetates, and $(\mathrm{EtO})_{2} \mathrm{P}(\mathrm{O}) \mathrm{CF}_{2} \mathrm{Br}$. The reasons for failure are unclear.

${ }^{c}$ Isolated yield of pure compounds after chromatography on silica gel. 